\title{
That-clause Subject/Object Asymmetry in Second Language Acquisition of ECP Principle by Iranian Learners
}

\author{
Marzieh Nezakat-alhossaini \\ English Department, Faculty of Foreign Languages, the University of Isfahan, Isfahan, Iran \\ Email: Nezakat_m@yahoo.com \\ Ahmad Moinzadeh \\ English Department, Faculty of Foreign Languages, the University of Isfahan, Isfahan, Iran \\ Email:amoinzad@hotmail.com
}

\begin{abstract}
This study is concerned with the question of whether Persian-speaking EFL learners recognize Empty Category Principle and 'that-trace' effect constraint. One-hundred fifty EFL learners participated in the study from among whom 90 language learners at Najafabad Azad University, selected by the OPT, participated in a decontextualized Grammaticality Judgment task. They were three groups of high, mid, and low. Another 60 English learners studying at Gooyesh Language Institute, selected based on their final scores, participated in a contextualized GJ task. They were two groups of 30 (high and mid). Two one-way ANOVAs were conducted for the decontextualized GJ task's results; one for each subject/objrct extraction tasks; two independent t-tests were conducted for the contextualized GJ task: one for each subject/object extraction tasks. It was concluded that participants of the study did not make a distinction between subject/object extractions and they did not recognize ECP and locality conditions in 'that' clauses.
\end{abstract}

Index Terms - that-trace effect, subject/object-extraction, ECP, GJ tasks

\section{INTRODUCTION}

'Wh-movement is a type of movement operation whereby a wh-expression is moved to the front of a particular type of structure (Radford, in press). It is a kind of movement by which an operator expression (i.e. who, what, when ...) moves into the specifier position within CP. There are different wh-question types in different languages.

Cheng (1991) makes a distinction between languages in terms of wh-movement, such as English, and the ones which keep the $w h$-word in-situ, such as Chinese and Persian. The former group is called wh-movement languages and the latter $w h$-in-situ. Considering minimalist assumptions, it is claimed that movement is triggered by an uninterpretable wh-feature [+WH] on C (Chomsky 1995); consequently, the wh-word moves to [spec, CP] or the derivation will crash. Within this framework languages which show $w h$-movement have strong uninterpretable features and as a result the $w h$ word moves overtly, i.e. prior to spell out, in order to check the uninterpretable feature.

As opposed to wh-movement languages which have overt $w h$-word movement, in languages like Chinese or Japanese, however, wh-phrases do not have to be displaced in overt syntax. Huang (1982) has extended the domain of inquiry by treating $w h$-in-situ in terms of LF movement. According to Huang's proposal, wh-phrases undergo LF movement after mapping to PF to produce LF representation. Huang's LF movement approach to $w h$-in-situ languages like Chinese makes it possible to directly compare wh-in-situ languages with English-type languages where wh-phrases are overtly displaced (Watanabe, 2003).

\section{A. Wh-movements in Persian}

Persian is an SOV language which shows a free word order. Lotfi (2003) believes that due to scrambling, which is a common phenomenon in Persian, in addition to the basic SOV word order; there are SVO, OSV, and OVS word orders. The following examples show the possible word orders in Persian:

(1a) rmin Elnaz-o did. (SOV)

Armin Elnaz-OM saw.

Armin saw Elnaz.

(b) rmin did Elnaz-o.

Armin saw Elnaz-OM

Armin saw Elnaz.

(c) Elnaz-o rmin did.

Elnaz-OM Armin saw

Armin saw Elnaz. 
(d) Elnaz-o did rmin

Elnaz-OM saw Armin.

(OVS)

Armin saw Elnaz.

As mentioned, scrambling lets Persian speakers to afford a variety of word orders which obeys movement restrictions; such as Minimal Link Conditions (MLC) (Karimi, 1999). Karimi and Taleghani (2007) suggest that the phrase structure of this language consists of two major domains (Karimi, 2005): the lexical domain and the operator/discourse domain. The lexical domain consists of VP, with $\mathrm{T}$ as an extension of this domain.

The operator/discourse domain consists of $\mathrm{CP}$, which could optionally include two topic positions, and a focus projection. Each one of these positions appears in a fixed order relative to others. This is presented in figure 1:

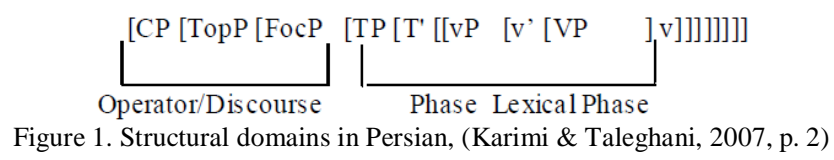

Persian is a topic prominent language in the sense of Kiss (1994, 1997, 1998, and 2003). That is, the element that moves out of the $v \mathrm{P}$ ranges over a number of different phrases, including the subject phrase. However, no element is extracted when the entire sentence is in focus. Furthermore, the language lacks structural passive, raising to subject, overt or covert expletives. Thus, the Spec of TP is not a typical subject position, but is projected when there is a background topic present in the clause. The Spec of TopP is reserved for another type of topic, most possibly a shifted topic in the sense of Karimi (2005).

Here some examples of $w h$-questions in Persian are reviewed to determine the property of movability in these questions. It is worth mentioning that these questions are unmarked; that is the most used by native speakers of Persian.

(2) a. ali hasan-o zad.

Ali Hassan-OM hit.PAST.3SG

'Ali hit Hassan'

b. ki Hasan-o zad?

Who Hassan-OM hit.PAST.3SG

'Who hit Hssan?'

c. ali ki-o zad?

Ali who-OM hit.PAST.3SG

'Who did Ali did?'

(3) a. ali ye ketab xarid.

Ali a book buy-PAST.3SG

'Ali bought a book.'

b. ali chi xarid?

Ali what buy-PAST.3SG

'What did Ali buy?'

The surface word order of the examples in (2) and (3) suggest that Persian is a wh-in-situ language, as the wh-words occupy the same positions in the questions as their counterparts in the declarative sentences (Kahnemuyipour, 2001).

\section{B. Universal Grammar and Second Language Acquisition}

L2 learners face a task parallel to that of L1 acquirers, namely to arrive at a linguistic system which accounts for the L2 input, allowing the learner to understand and speak the second language. Given this apparent similarity, the question of whether UG also mediates L2 acquisition, and to what extent, has been investigated and debated since the early 1980s. The first decade of research on UG in L2 acquisition concentrated largely on the so-called access issue, namely, whether or not UG remains available in non-primary acquisition. This research has looked for evidence that L2 learners can (or cannot) apply principles of UG, and set or reset parameters, as well as investigating the extent to which the mother tongue (L1) was involved, for example through the adoption of L1 parameter settings in interlanguage grammars. Hypotheses varied as to whether L2 learners have no access, direct access or indirect access to UG.

One side of the debate, sometimes referred to as the no access position (for example, Cook 1988; Cook and Newson 1996; Epstain, Flynn and Martohardjono 1996), is represented by the Fundamental Difference Hypothesis (BleyVroman 1990) and related claims (Clahsen and Muysken 1986; Schachter 1988). According to this view child L1 and adult L2 differ in major respects. Proponents claim that adult L2 acquisition is not constrained by UG, or that is only constrained by UG insofar as universal properties can be accessed via the L1 grammar.

On the other side of the debate is the position that L2 learners indeed have access to UG. Among the SLA research on the direct access Flynn, 1984; 1987; 1988; Mazurkewich, 1988; White, 1988 and Ohba, 2007 can be seen. An alternative kind of account recognized the role of both the L1 and UG: L2 learners are indeed assumed to have access to principles and parameters of UG. However, initially at least, access would be via the L1 grammar, with the possibility of subsequent grammar restructuring and parameter resetting, in the light of exposure to L2 input (e.g. White 1985, 2003). This position is sometimes referred to as indirect access. 


\section{The Empty Category Principle}

According to minimalist assumptions there are some constraints on the way movements. Empty Category Principle is a principle according to which empty categories should be properly governed. They should be lexically/head governed, i.e. governed by a phrase head/ $\mathrm{X}^{0}$ or antecedent-governed, i.e. bound by (co indexed with and c-commanded) by a category that governs them (Lasnik and Saito, 1992). As the example below shows: $t$ is ungoverned, therefore the sentence is ungrammatical:

(4) *Terry is crucial $t$ to pay the bill

Well-known examples of ECP-violations are extractions of an adjunct out of an island as in (5) (containing a whisland) and configurations displaying the that-trace effect in English, as in (6). In both cases, the trace cannot be properly antecedent-governed because of the intervention of a barrier.

(5) * how $_{\mathrm{i}}$ did John ask [whether Bill fixed the car $\mathrm{t}_{\mathrm{i}}$ ]

(6) $*$ who $_{\mathrm{i}}$ does John believe [that $\mathrm{t}_{\mathrm{i}}$ will fix the car]

One obstacle on the way of governing of the empty categories is the that-trace effect. According to Pesetsky and Torrego 2001 the that-trace effect is as follows:

(7) a. whom $_{\mathrm{i}}$ do you think $\left[_{\mathrm{cp}}\right.$ that $\left[{ }_{\mathrm{IP}}\right.$ Lord will invite $\left.\mathrm{t}_{\mathrm{i}}\right]$ ?

b. whom ${ }_{i}$ do you think $\left[\mathrm{cp}\left[\mathrm{IP}\right.\right.$ Lord will invite $\left.\mathrm{t}_{\mathrm{i}}\right]$ ?

(8) a. * who $_{\mathrm{i}}$ do you think [CP that $\left[{ }_{\mathrm{IP}} \mathrm{t}_{\mathrm{i}}\right.$ will arrive first] $]$ ?

b. who $\mathrm{o}_{\mathrm{i}}$ do you think $\left[{ }_{\mathrm{CP}}\left[{ }_{\mathrm{IP}} \mathrm{t}_{\mathrm{i}}\right.\right.$ will arrive first $\left.]\right]$ ?

This effect is most often attributed to a local binding requirement on subject traces — the Empty Category Principle (ECP) (Lasnik and Uriagereka, 2005). The presence of the word that in examples like (8b) which have undergone whmovement, is taken to block a crucial government relationship between the subject trace and some element in the Csystem (In some accounts, the relevant member of the C-system is C itself (e.g. Rizzi, 1990). In others, it is an intermediate trace of successive-cyclic movement (Kayne, 1980; Pesetsky 1982).

The point is that objects can be extracted across overt complementizers as in (7) but subjects can only be extracted from clauses without overt complementizers (8). As discussed in ECP, traces of movements should be fully governed, both lexically and antecedent governed. The grammaticality of $(7 a, b)$ is because the trace is a direct object, which is well governed. The existence of the complementizer that makes no difference here and the trace of the extracted object is fully governed. The grammaticality of ( $8 b)$ is because the trace of the extracted subject is governed and the ECP is satisfactorily met. The ungrammaticality of $(8 \mathrm{a})$ is because the trace of the extracted subject can not be governed, since the governing process is blocked by the complementizer that which is intervening between the trace and its antecedent which should govern it. And also it is not lexically governed, because, it is not a complement of a head.

As mentioned earlier, Persian is a focus fronting language considering wh-movements which is a very different feature from that of English; the movement to the specifier CP. Consequently the constraints on the way of movements do not exist in this language as it is shown below:

(9) a. Mina goft-3Per-Past ke Ali zudtar resid-3Per-Past

Mina said that Ali earlier arrived

Mina said that Ali arrived earlier

b. Mina goft-3Per-Past ke ki zudtar resid-3Per-Past?

Mina said that who earlier arrived?

*Who did Mina say that arrived earlier?

This difference brings the question of whether Persian L2 learners of English will have difficulty learning these principles and their constraints or not? The research questions are as below:

1. Can Iranian L2 learners of English (L1=Persian) recognize the Empty Category Principle (i.e. ECP)?

2. Can Iranian L2 learners of English (L1=Persian) recognize the locality requirements in terms of subject/object extractions from that-clauses; i.e. the 'that-trace effect'.

3. Is there a relationship between the proficiency level of Iranian L2 learners of English (L1 Persian) and the availability of Universal grammar Principles (i.e. empty Category Principle)?

4. Do Iranian L2 learners of English (L1=Persian) have access to UG principles (i.e. Empty Category Principle)?

\section{Methodology}

\section{A. The Pilot Study}

A pilot study was conducted among a group of 90 English learners at Gooyesh Language Institute, Isfahan-Iran. Three groups of 30 were chosen from among these students. The criterion was the institute's placement tests. They were given a contextualized GJ task consisting of 10 conversations. Meanwhile the tests were checked by a native speaker. Based on the researcher's observation, the elementary group were not able to understand the conversations and the bold sentences since they were beyond their proficiency level. Therefore the elementary group was excluded in the main study. After the data collection and analysis, the number of conversations changed to 14 . This was done because of statistical reasons in order to have an equal number of questions on object and subject extractions. The first test consisted of four subject extractions and six object extractions that caused some statistical problems; at the same time, 
there were some words that had to be exchanged with some others to enhance the understanding rate of the factors in question (that-trace effect).

\section{B. Participants}

The participants of the study were selected from among Iranian second language learners of English. Two groups of these learners were chosen. The first group consisted of 130 students randomly selected from among university students of TEFL at Najaf Abad Azad University, Isfahan-Iran. This group took part in an Oxford Placement Test (OPT). The results of the OPT led to the selection of three groups, each containing 30 students. The remaining 40 were disregarded according to the instructions of grouping, provided by OPT developers which led to three statistically significant groups of high, mid, and low.

Another group of Iranian L2 learners were chosen from among Iranian English learners at Gooyesh Language Institute, Isfahan-Iran. They were a group of 60 students who were randomly selected; and were studying in Intermediate and Advanced levels of the institute (according to the institute's evaluations). Two groups of 30 were chosen from among these students (based on the results of the pilot study, no low group was selected). The criterion was the students' final scores in the last four terms.

For the intermediate group, they were all studying in the last term of the intermediate level (there are four terms for intermediate students); the students' scores in the last four terms were between 80-85 and the advanced group's scores who were again studying in the last term of the advanced level (there are four terms for advanced students) were between 75-80. Therefore, the groups were totally homogeneous in terms of proficiency.

\section{Materials}

\section{Oxford Placement Test (OPT)}

The Oxford Placement Test (Allen, 1992) was used in order to decide on the proficiency levels of those participated in the Decontextualized GJ task. The test contains 200 items and has two main parts. The first part deals with the listening test including 100 items. The participants listen to sentences read by a native speaker and choose one of the two options provided in each sentence. The second part which consists of 100 test items of grammar is divided into two fifty-item subsections where participants should choose one of the three options provided in each sentence. The proficiency level of the participants is decided on a table provided by the test maker.

\section{The decontextualized GJ task}

The task contained 30 wh-questions: 20 questions on the factor in question (subject/object extraction from 'that' clauses) and 10 distractors; the distractors, simple wh-questions, were divided into two five groups of grammatical and ungrammatical; among the remaining 20, there were 10 subject-extraction wh-questions which were divided into five grammatical and five ungrammatical and the remaining 10 were object-extractions. Here are some samples:

a) What did John regret that he saw? (Object-extraction wh-question)

b) Who do you think will arrive first? (Grammatical subject-extraction wh-question)

c) Who do you think that will win the race? (Ungrammatical subject-extraction wh-question)

d) Which chair did Mr. James sit on? (Grammatical distractors)

e) Which telephone did ring? (Ungrammatical distractors)

All 30 questions were chosen from related texts on that-trace effect which were all written by the native authors.

\section{The contextualized GJ task}

The task contained 14 conversations between two speakers. In each conversation, a situation was given at the beginning and then at the end there was a wh-question written in bold on the factor in question (subject/objectextraction). The subjects were supposed to judge on the degree of acceptability of these questions after reading the whole conversation. There were seven subject-extraction and seven object-extraction $w h$-questions. The questions were checked by a native speaker and some changes were done based on his comments. The reason that this type of task was used in this study was, to have a different type of question which was contextualized and could reduce the possible ambiguities in a decontextualized task. Another reason for conducting such a task was a kind of double checking on the data obtained from the decontextualized GJ task.

\section{Procedure}

\section{The decontextualized GJ task}

The 90 participants chosen through the OPT took part in a decontextualized GJ task. The task contained 30 whquestions on subject/object extractions from 'that' clauses. There were 10 distractors to reduce the sensitivity of the test on the part of the participants. There were another 10 questions on object-extraction which were all grammatical in the sense that there was no ungrammatical version of these questions according to the 'that-trace' effect principle.

The remaining 10 were on subject-extraction which consisted of five grammatical and five ungrammatical extractions. The participants were asked to give scores to the sentences based on their judgments on the degree of acceptability of the sentences. The instructions were given in Persian. They were given a scale as below:

\begin{tabular}{|c|c|c|c|c|c|}
\hline & 5 & 4 & 3 & 2 & 1 \\
\hline & $100 \%$ & $75 \%$ & $50 \%$ & $25 \%$ & $0 \%$ \\
\hline
\end{tabular}


The participants were supposed to give a score, ranging from 1 to 5 , based on the degree of acceptability of the sentences given. As shown in the scale above, 1 indicates $0 \%$ which means it is not acceptable at all to 5 that indicates $100 \%$ and means it is totally acceptable. The scoring was as follows. For grammatical questions, the score given by the participant was the true score of the participant. It means if a participant recognizes a grammatical object or subjectextraction and gives 5 to it, the score 5 is going to be counted; or if she/he recognizes the same question as mostly acceptable and gives a 3, the very score will be counted. The scoring of the ungrammatical questions is the reverse process. If a participant recognizes an ungrammatical subject-extraction as grammatical and gives a score of 5 to it, she/he gets 1 because of the wrong judgment on the test. If she/he recognizes the ungrammatical sentence as ungrammatical and gives a score of 1 to it, she/he gets 5 because of the correct judgment on the question given. The total score of the object and subject-extractions was the same which was 50.

\section{Contextualized GJ task}

This test was given to a group of 60 English learners at Gooyesh Language Institute who were divided into two groups of 30 . The test consisted of 14 conversations; seven items contained object-extractions and seven items contained subject-extractions. Each conversation had a situation at the beginning to make the ground clear to the participants. At the end of each conversation, there was a wh-question on subject/object extraction written in bold which the students were asked to judge on the degree of acceptability of the sentence. The scoring process was the same as the decontextualized GJ task, and the instructions were given in Persian.

\section{RESULTS}

\section{A. $O P T$}

The participants of the study who later participated in the decontextualized test, took part in an OPT and were divided into three groups of high, mid, and low according to their proficiency level. The mean scores of which are presented in Table 1. The high group $105.43(\mathrm{SD}=4.28)$, mid group $91.93(\mathrm{SD}=1.79)$, and the low group $75(\mathrm{SD}=$ 37).

TABLE I.

DESCRIPTIVE DATA CONCERNING THE OPT

\begin{tabular}{|ll|l|l|l|}
\hline & & N & Mean & Std. Deviation \\
\hline $\begin{array}{l}\text { Dependent } \\
\text { variable }\end{array} \quad$ Groups & & & \\
\hline OPT & High & 30 & 105.4333 & 4.28054 \\
\hline Mid & 30 & 91.9333 & 1.79911 \\
\hline Low & 30 & 75.0000 & 9.96546 \\
\hline Total & 90 & 90.7889 & 14.00521 \\
\hline \multicolumn{2}{|r|}{} \\
\hline \multicolumn{2}{|r|}{}
\end{tabular}

A one-way analysis of variance was conducted as the OPT scores to be dependent variable and the three groups of high, mid, and low as the independent variables:

TABLE II.

ONE-WAY ANOVA FOR OPT

\begin{tabular}{|ll|l|l|l|l|l|}
\hline $\begin{array}{l}\text { Dependant } \\
\text { Variable }\end{array}$ & $\begin{array}{l}\text { Sum of } \\
\text { Squares }\end{array}$ & df & Mean Square & F & Sig. \\
\hline OPT Between Groups & 13951.756 & 2 & 6975.878 & 173.142 & .000 \\
\hline \multicolumn{2}{|l|}{ Within Groups } & 3505.233 & 87 & 40.290 & & \\
\hline Total & 17456.989 & 89 & & & \\
\hline
\end{tabular}

There was a statistically significant difference among the groups $(\mathrm{F}=173.14, \mathrm{p}<0.01)$. However, in order to detect the exact location of the difference, a post hoc Scheffe test was conducted; the results are presented in Table 3:

TABLE III.

THE POST-HOC TEST FOR THE OPT

\begin{tabular}{|c|c|c|c|c|c|c|c|}
\hline \multirow[t]{2}{*}{ Test } & $\begin{array}{l}\text { (I) } \\
\text { Language } \\
\text { Level }\end{array}$ & $\begin{array}{l}\mathrm{J}) \\
\text { Language } \\
\text { Level }\end{array}$ & $\begin{array}{l}\text { Mean } \\
\text { Difference (I- } \\
\text { J) }\end{array}$ & Std. Error & Sig. & \multicolumn{2}{|c|}{$95 \%$ Confidence Interval } \\
\hline & & & & & & $\begin{array}{l}\text { Lower } \\
\text { Bound }\end{array}$ & $\begin{array}{l}\text { Upper } \\
\text { Bound }\end{array}$ \\
\hline \multirow[t]{6}{*}{ Scheffe } & High & Mid & $13.5000(*)$ & 1.63890 & .000 & 9.4183 & 17.5817 \\
\hline & & Low & $30.4333(*)$ & 1.63890 & .000 & 26.3516 & 34.5150 \\
\hline & Mid & High & $-13.5000(*)$ & 1.63890 & .000 & -17.5817 & -9.4183 \\
\hline & & Low & $16.9333(*)$ & 1.63890 & .000 & 12.8516 & 21.0150 \\
\hline & Low & High & $-30.4333(*)$ & 1.63890 & .000 & -34.5150 & -26.3516 \\
\hline & & Mid & $-16.9333(*)$ & 1.63890 & .000 & -21.0150 & -12.8516 \\
\hline
\end{tabular}

$*$ The mean difference is significant at the .05 level. 
According to the results, the high group performed significantly better $(\mathrm{M}=105.43, \mathrm{SD}=4.28)$ than the mid group $(M=91.93, S D=1.79)$ and the low group $(M=75, S D=37)$. Furthermore, the mid group $(M=91.93, S D=1.79)$ performed significantly better than the low group $(\mathrm{M}=75, \mathrm{SD}=37)$.

\section{B. Decontextualized Test}

The task contained two kinds of wh-questions; subject-extraction and object-extraction from that-clauses.

\section{Subject extraction}

The means for the groups were $30.36(\mathrm{SD}=3.51), 30.06(\mathrm{SD}=3.80)$, and $28.66(\mathrm{SD}=3.71)$ for the high, mid, and low groups respectively:

TABLE IV.

DESCRIPTIVE STATISTICS FOR SUBJECT-EXTRACTIONS FROM THAT-CLAUSES

\begin{tabular}{|c|c|c|c|c|c|}
\hline \multicolumn{2}{|c|}{$\begin{array}{l}\text { Dependent } \\
\text { Variable } \\
\text { Groups }\end{array}$} & $\mathrm{N}$ & Mean & Std. Deviation & Std. Error \\
\hline SE & High & 30 & 30.3667 & 3.51826 & .64234 \\
\hline & Mid & 30 & 30.0667 & 3.80502 & .69470 \\
\hline & Low & 30 & 28.6667 & 3.71700 & .67863 \\
\hline Tot: & & 90 & 29.7000 & 3.71589 & .39169 \\
\hline
\end{tabular}

To answer the research questions concerning the degree of the participants', recognition of the ECP and its first locality requirement subject-extraction in that-clauses, as well as investigating whether there was a significant difference in performance among the three proficiency groups of high, mid, and low in the decontextualized GJ task containing subject-extractions, a one-way analysis of variance was conducted. The related dependent and independent variables were the proficiency groups and subject-extraction respectively:

TABLE V.

\begin{tabular}{|l|l|l|l|l|l|}
\hline \multicolumn{1}{|l}{ ONE-WAY ANOVA FOR SUBJECT-EXTRACTION FROM THAT-CLAUSES } \\
\hline & $\begin{array}{l}\text { Sum of } \\
\text { Squares }\end{array}$ & df & Mean Square & F & Sig. \\
\hline Between Groups & 49.400 & 2 & 24.700 & 1.822 & .168 \\
\hline Within Groups & 1179.500 & 87 & 13.557 & & \\
\hline Total & 1228.900 & 89 & & & \\
\hline
\end{tabular}

The results showed no significant difference among the three proficiency groups in terms of recognizing the ECP principle and its first locality requirement subject-extraction from that-clauses $(\mathrm{F}=1.822, \mathrm{p}<0.01)$.

Object-extraction

Table 6 presents the mean scores for the second constraint in ECP principle; object-extraction. The mean scores were $37.13(\mathrm{SD}=6.04)$ for the high group, $35.43(\mathrm{SD}=6.53)$ the mid group and $34.70(\mathrm{SD}=6.01)$ fir the low group:

TABLE VI. DESCRIPTIVE STATISTICS FOR OBJECT-EXTRACTION FROM THAT-CLAUSES

\begin{tabular}{|ll|l|l|l|l|}
\hline $\begin{array}{l}\text { Dependent } \\
\text { Variable }\end{array}$ & Groups & $\mathrm{N}$ & Mean & Std. Deviation & Std. Error \\
\hline OE & High & 30 & 37.1333 & 6.04998 & 1.10457 \\
\hline Mid & 30 & 35.4333 & 6.53206 & 1.19259 \\
\hline Low & 30 & 34.7000 & 6.01808 & 1.09875 \\
\hline Total & 90 & 35.7556 & 6.21942 & .65558 \\
\hline
\end{tabular}

A one-way analysis of variance, proficiency groups being the dependent variable and the constraint object-extraction the independent variable, was consequently conducted to answer the research question concerning the recognition of the ECP principle by the participants on the one hand and the degree of locality requirement recognition, object-extraction in that-clauses on the other:

TABLE VII.

ONE-WAY ANOVA FOR OBJECT-EXTRACTION FROM THAT-CLAUSES

\begin{tabular}{|l|l|l|l|l|l|}
\hline & $\begin{array}{l}\text { Sum of } \\
\text { Squares }\end{array}$ & df & Mean Square & F & Sig. \\
\hline Between Groups & 93.489 & 2 & 46.744 & 1.214 & .302 \\
\hline Within Groups & 3349.133 & 87 & 38.496 & & \\
\hline Total & 3442.622 & 89 & & & \\
\hline
\end{tabular}

The results showed no significant difference among the three groups in terms of recognizing the ECP principle and its second locality requirement object-extraction from that-clauses $(\mathrm{F}=1.21, \mathrm{p}<0.01)$.

C. Contextualized GJ Task 
The second means of data collection was a contextualized GJ task. The task contained 14 conversations containing wh-questions. There were two types of questions; subject-extraction and object-extraction from that-clauses. After scoring the tests, some data was obtained based on which, the following statistical procedures were done.

\section{Subject-extraction}

Table 8 presents the mean scores concerning subject-extraction from that-clauses. The means were 20.5 $(\mathrm{SD}=2.66)$, and $21(\mathrm{SD}=3.57)$ for the high and mid groups respectively:

TABLE VIII.

DESCRIPTIVE STATISTICS FOR SUBJECT-EXTRACTION FROM THAT-CLAUSES

\begin{tabular}{|l|l|l|l|l|l|}
\hline $\begin{array}{l}\text { Dependent } \\
\text { variable }\end{array}$ & Groups & $\mathrm{N}$ & Mean & Std. Deviation & Std. Error Mean \\
\hline $\begin{array}{l}\text { Subject- } \\
\text { extraction }\end{array}$ & High & 30 & 20.5000 & 2.66199 & .48601 \\
\cline { 2 - 6 } & Mid & 30 & 21.0000 & 3.57192 & .65214 \\
\hline
\end{tabular}

An independent-sample t-test was conducted to compare the high and mid groups based on subject-extractions:

TABLE IX

INDEPENDENT T-TEST FOR SUBJECT-EXTRACTION FROM THAT-CLAUSES

\begin{tabular}{|l|l|l|l|l|l|l|l|l|}
\hline $\mathrm{F}$ & Sig. & $\mathrm{t}$ & $\mathrm{df}$ & $\begin{array}{l}\text { Sig. (2- } \\
\text { tailed) }\end{array}$ & $\begin{array}{l}\text { Mean } \\
\text { Difference }\end{array}$ & \multicolumn{2}{|l}{$\begin{array}{l}\text { Std. Error } \\
\text { Difference }\end{array}$} & \multicolumn{2}{l}{$\begin{array}{l}\text { 95\% Confidence Interval of } \\
\text { the Difference }\end{array}$} \\
\hline $\begin{array}{l}1.32 \\
7\end{array}$ & .254 & -.615 & 58 & .541 & -.50000 & .81332 & -2.12804 & 1.12804 \\
\hline & & -.615 & 53.619 & .541 & -.50000 & .81332 & -2.13088 & 1.13088 \\
\hline
\end{tabular}

There was no significant difference in scores for the high group $(\mathrm{M}=30.36, \mathrm{SD}=3.51)$, and mid group $\mathrm{M}=30.06, \mathrm{SD}=$ $3.80 ; \mathrm{t}(58)=.615, \mathrm{p}=.54$ (two-tailed) with regard to subject-extraction from that-clauses in contextualized GJ task.

Object-extraction

Table 10 presents the mean scores for object-extraction from that-clauses. The mean scores are $26.53(\mathrm{SD}=3.90)$, and $26(\mathrm{SD}=5.63)$ for the high and mid groups:

TABLE X.

DESCRIPTIVE STATISTICS FOR OBJECT-EXTRACTION FROM THAT-CLAUSES

\begin{tabular}{|c|c|c|c|c|c|}
\hline $\begin{array}{c}\text { Dependent } \\
\text { Variable }\end{array}$ & Groups & $\mathrm{N}$ & Mean & Std. Deviation & $\begin{array}{c}\text { Std. Error } \\
\text { Mean }\end{array}$ \\
\hline $\begin{array}{c}\text { Object } \\
\text { extraction }\end{array}$ & High & 30 & 26.5333 & 3.90166 & .71234 \\
\cline { 2 - 6 } & Mid & 30 & 26.0000 & 5.63854 & 1.02945 \\
\hline
\end{tabular}

An independent-sample t-test was conducted to compare the results obtained from the object-extraction tasks for the two groups of high and mid:

TABLE XI.

INDEPENDENT T-TEST FOR OBJECT-EXTRACTION FROM THAT-CLAUSES

\begin{tabular}{|l|l|l|l|l|l|l|l|l|}
\hline & F & Sig. & $\mathrm{t}$ & $\mathrm{df}$ & Sig. (2-tailed) & $\begin{array}{l}\text { Mean } \\
\text { Difference }\end{array}$ & $\begin{array}{l}\text { Std. Error } \\
\text { Difference }\end{array}$ & \multicolumn{2}{l|}{$\begin{array}{l}\text { 95\% Confidence Interval of } \\
\text { the Difference }\end{array}$} \\
\hline 6.578 & .013 & .426 & 58 & .672 & .53333 & 1.25188 & -1.97258 & 3.03924 \\
\hline & & .426 & 51.592 & .672 & .53333 & 1.25188 & -1.97922 & 3.04589 \\
\hline
\end{tabular}

There was no significant difference in scores for the high group $(\mathrm{M}=26.53, \mathrm{SD}=3.90)$, and mid group $\mathrm{M}=26$, $\mathrm{SD}=5.63 ; \mathrm{t}(58)=.426, \mathrm{p}=.67$ (two-tailed) in terms of object-extraction from that-clauses in contextualized GJ task.

\section{DisCUSSION}

This study tried to compare two different languages based on their behavior toward wh-movements. Persian as opposed to English is a wh-in-situ language or in other words, a focus fronting language in which no movements take place while making wh-questions and the wh-expressions remain in-situ and at least there is no movement to spec $\mathrm{CP}$ position as there is in English. To have different types of movement operations in Persian leads to having different constraints from those of English. We tried to understand whether this difference would be problematic for Iranian learners of English or not.

The first research question was to see whether Iranian L2 learners of English (L1=Persian) can recognize the Empty category Principle (ECP). Traces of moved phrases are subject to the ECP. ECP exits in both kinds of extractions from that-clauses; it is a constraint when there is a subject-extraction; it is not a constraint when there is an object extraction though. The data obtained from both types of tests (decontextualized and contextualized GJ tasks), showed that Iranian L2 learners of English participated in this study were not fully aware of this principle and overruled it during the tasks.

The second research question was whether Iranian L2 learners of English (L1=Persian) could recognize the locality requirements in terms of subject/object-extractions from that-clauses; i.e. the 'that-trace effect'. The locality 
requirement for extracting from that-clauses while making wh-questions is to omit the complementizer that when extracting the subject, while removing it when extracting the object is not necessary. The data obtained from both types of tasks which were decontextualized and contextualized GJ tasks, showed that, Iranian L2 learners of English could not make a distinction between subject and object extraction from that-clauses, therefore, they moved the elements (object/subjects) from those clauses with no regard to the principles in question. Therefore, they did not recognize the 'that-trace effect' principle.

The third research question questioned the availability of UG with regard to Iranian L2 learners of English. According to Chomsky (1980), "UG is the set of properties, conditions, or whatever that constitutes the "initial" state of the language learner, hence the basis on which knowledge of language develops". According to this idea, UG is supposedly available to L1 learners. The question is whether it is available to L2 learners as well. Based on the data obtained in this study, the Iranian L2 learners of English who participated in this study could not recognize the UG principles and therefore did not have access to the UG principle in question, the Empty Category Principle (ECP). This finding is in line with Hawkins and Hattori (2006) who investigated the sensitivity of high proficiency Japanese speakers of English to superiority in bicultural sentences. Ameri-Golestan (2001), in another attempt, dealt with presentational and presuppositional arguments with regard to Subjacancy principle, and Tsimpli and Dimitrakopoulou (2007) on interpretability hypothesis and evidence from wh-interrogatives in Greek second language learners of English (cf. Yu-Chang, 2009).

The fourth research question investigated the relationship between the proficiency level of the participants and the availability of Universal Grammar Principles (i.e. ECP). Based on the results discussed above, there was no significant difference among the three groups of high, mid, and low in the decontextualized GJ tasks and between the two groups of high and mid in the contextualized GJ tasks. Therefore it can be concluded that there was no relationship between the proficiency level of the participants in this study and the availability of Universal Grammar principles (i.e. ECP).

The results obtained from both decontextualized and contextualized GJ tasks indicate that the Iranian L2 learners participated in this study were not able to recognize neither the 'that-trace effect' principle nor the Empty Category Principle and overruled them.

\section{CONCLUSION}

The findings of the present study can be best explained by the maturation theory according to which the function that 'maps' acoustic input to knowledge undergoes change. That is, the mapping function is defined as UG itself. As such, UG will be different at different developmental stages in language acquisition. Such a model would suggest that for a language learner (L1 or L2), hearing sentences containing examples of a particular syntactic structure does not necessarily trigger knowledge of the structure (Cook, 2002).

For example, hearing the sequence of language sounds associated with the utterance 'John was arrested' does not give the learner the ability to understand that 'John' is the object of the verb 'arrested'. At some later developmental stage, however function defined as UG changes in such a way that such data-exposure does lead to a change in the learner's grammar.

This is because a maturational model would appear to predict that once a parametric value is established, the alternative value would cease to be available to the L2 learner if needed for the construction of a new target grammar. Only if the L2 can be directly modeled on L1 constructions can new language acquisition occur. Only a parameter value instantiated in the L1 would be directly available under the Maturation model.

UG in this model is not distinct from the language-specific grammar in the end state, and consequently the adult cannot access UG again, after the 'initial state', defined as S0. New language knowledge must of necessity be accessed through some other means, perhaps through L1 in some transfer-based way. The Maturation model would be predicted to hold, for example, if maturation under some form of genetic programming underlay much of the essential course of L1 acquisition. Presumably there would be actual 'brain change' (as yet undefined) under this model, which correlates with the course of acquisition of an L1. The brain would never be in the same state again in this model, after the language state S1 (or perhaps more accurately, state zero [S0]), with respect to the language faculty.

Adults, therefore, tend to use the general problem solver when attempting to learn language. Thus, these classroom learners are learning language in the way they would learn any other subject. They have conscious knowledge of the forms they have been taught and they apply only that language; they do not generalize beyond it; where they have not been taught, they deal with the problem as best as they can by transferring their knowledge of the L1 system. They are always conservative about generalizing into new areas, and the more advanced they are, the more wary the generalizations become.

\section{REFERENCES}

[1] Allen, C. (1992). Oxford Placement Test. Oxford: Oxford University Press.

[2] Ameri Golestan, A. (2001). Extraction from presentational and presuppositional constructions in Iranian L2 learners' English interlanguage. MA Thesis: Khorasgan Azad University.

[3] Bley-Vroman, R. (1990). The logical problem of foreign language learning. Linguistics Analysis 20, 3-49.

[4] Cheng, L. (1991). Typology of wh-questions. PhD Dissertation. MIT. 
[5] Chomsky, N. (1980). Rules and representations. New York: Columbia University Press.

[6] Chomsky, N. (1995). Minimalist Program. Cambridge, MA: MIT Press.

[7] Clashen, H. \& Muysken, P. (1986). The availability of Universal Grammar to adult and child learners: A study of the acquisition of German word order. Second Language Research 2, 93-119.

[8] Cook, V. J. (1988). Chomsky’s Universal Grammar: An introduction. Oxford: Basil Blackwell.

[9] Cook, V. \& Newson, M. (1996). Chomsky's Universal Grammar. Oxford: Basil Blackwell.

[10] Cook, V. (2002). Portrait of the L2 User. UK: Clevedon Multilingual Matters.

[11] Epstein, S., Flynn, S., \& Martoharjono, G. (1996). Second language acquisition: theoretical and experimental issues in contemporary research. Brain and Behavioral Sciences 19, 677-758.

[12] Flynn, S. (1984). A universal in L2 acquisition based on a PBD typology. In F. Eckman, L. Bell, \& D. Nelson (Eds.), Universals of second language acquisition. Rowley, MA: Newbury House.

[13] Flynn, S. (1987). A Parameter-setting of L2 acquisition. Dordrecht: Reidel.

[14] Flynn, S. (1988). Nature of development in L2 acquisition and implications for theories of Language acquisition in general. In Flynn and O'Neil (eds). Linguistic theory in second language acquisition. Dordrecht: Kluwer Academic Publishers. 76-89.

[15] Hawkins, R. \& Hattori, H. (2006). Interpretation of English multiple wh-questions by Japanese speakers: a missing uninterpretable feature account. Second Language Research 22-3, 269-301.

[16] Huang, C.T. J. (1982). Logical relations in Chinese and the theory of grammar. Ph.D. dissertation, MIT.

[17] Kahnemuyipour, A. (2001). On wh-questions in Persian. Canadian Journal of Linguistics 46, 41-61.

[18] Karimi, S. (1999). Is scrambling as strange as we think. MIT Working Papers in Linguistics 33, 159-189.

[19] Karimi, S. (2005). A Minimalist approach to scrambling: Evidence from Persian. Berlin: Mouton de Gruyter.

[20] Karimi, S. \& Taleghani. A. (2007). Wh-movement, interpretation, and Optionality in Persin.In S. Karimi, V. Samiian, \& W. Wilkins (eds.), Clever and Right: Papers in Honor of Joseph Emonds. Berlin: Mouton de Gruyter.

[21] Kayne, R. S. (1980). ECP extensions. Linguistic Inquiry 12, 93-133.

[22] Kiss, E. K. (1994). Scrambling as the first generation of random complement order. In N. Cover and Riemsddijk, H. (eds), Study on Scrambling: Movement and Non-movement Approaches to Free order Phenomenon. Berlin: Mouton de Gruyter, 22156.

[23] Kiss, É. K. (1997). Discourse configurationality in the languages of Europe. In A. Siewierska (ed.), Constituent Order in the Languages of Europe. Berlin: Mouton de Gruyter.

[24] Kiss, É. K. (1998). Identificational focus versus information focus. Language 74.2, 245-273.

[25] Kiss, É. K. (2003). Argument scrambling, operator movement, topic movement in Hungarian. In S. Karimi, (ed.), Word Order and Scrambling. Oxford: Blackwell Publishers, 22-44.

[26] Lasnik, H. \& Saito, M. (1992). Move a. Cambridge, MA: MIT Press.

[27] Lasnik, H. \& Uriagereka, J. (2005). A course in Minimalist syntax. Oxford: Blackwell

[28] Lotfi, A. R. (2003). Persian wh-riddle. In Boeckx and Grohmann (eds.), Multiple Wh-Fronting. Amsterdam: John Benjamin.

[29] Mazurkewich, I. (1988). The Acquisition of Infinitive and Gerund Complements by Second Language Learners. In Flynn and O’Neil (eds). Linguistic Theory and Second Language Acquisition. 127-43. Dordrecht: Kluwer.

[30] Ohba, H. (2007). The acquisition of wh-movement in English questions and relative clauses by native speakers of Japanese. Doctoral dissertation. University of Essex.

[31] Pesetsky, D. (1982). Paths and categories. Doctoral Dissertation. MIT.

[32] Pesetsky, D. \& Torrego, E. (2001). T-to-C movement: Cause and consequences. In Michael Kenstowicz, MIT Press.

[33] Radford, A. (in press). Analysing English sentences: a minimalist approach. Cambridge: Cambridge University Press.

[34] Rizzi, L. (1990). Relativized minimality. Cambridge, MA: MIT Press.

[35] Schachter, J. (1988). Second language acquisition and its relationship to Universal Grammar. Applied Linguistics 9, $219-235$.

[36] Tsimpli L. M. \& Dimitrakopoulou, M. (2007). The interpretability hypothesis: evidence from wh-interrogatives in second language acquisition. Second Language Research 23.2, 215-242.

[37] Watanabe, A. (2003). Wh-in-situ languages. In M. Baltin, \& Ch. Collins (eds.), The Handbook of Contemporary Syntax, 203225.

[38] White, L. (1985). The pro-drop parameter in adult second language acquisition. Language Learning 35, 47-62.

[39] White, L. (1988). Universal grammar and second language acquisition. Amsterdam: Benjamins.

[40] White, L. (2003). Universal grammar and second language acquisition. Amsterdam: Benjamins.

[41] Yu-Chang, L. (2009). Do L2 Grammars Go Beyond the L1 and L2 Input? In Proceedings of the 3rd Conference on Generative Approaches to Language Acquisition North America (GALANA 2008), ed. Jean Crawford, Koichi Otaki, and Masahiko Takahashi, 139-147.

Marzieh Nezakat-Alhossaini is a Ph.D. student of Applied Linguistics at the University of Isfahan, Isfahan, Iran. She received an MA in TEFL from Islamic Azad University, Najafabad branch, Isfahan, Iran. Her main research interest areas are SLA and syntax. At present, she teaches ESP courses at Isfahan University of Medical Sciences, Isfahan, Iran.

Ahmad Moinzadeh is an associate professor of the faculty of foreign languages, English Department at the University of Isfahan, Isfahan, Iran. He received an MA in TEFL from Ferdosi Mashhad University, Mashhad, Iran. He received his Ph.D. from the University of Ottawa, Canada. At present he runs Linguistics, Applied Linguistics, Second Language Acquisition, and First Language Acquisition courses. He has published several articles in the field of TEFL and has supervised many dissertations and theses. 